\title{
THE WRITINGS OF JUDGE GEORGE G. WRIGHT VII
}

\author{
Associates on the Supreme Bench
}

William G. Woodward was elected to the bench with myself, also Norman W. Isbell. Woodward lived in Muscatine, Isbell in Marion, Linn County. It was at the session that Harlan was elected to the Senate-the election held to be irregular-denied his seat, and he was again elected. Woodward and myself were elected [on the] first ballot. There were seven to nine old-time Whigs. The Republican party, called Anti-Nebraska party, was just taking form, the old Whig party disbanding. These seven to nine old Whigs still had a holy horror of what were known as Abolitionists. Isbell was suspected, and justly perhaps, of being, as they said, too black, and these old conservatives refused to vote for him, and without their votes, or a good part of them, he could not get through. Soon, however, enough of the men "gamoused these allies of rebellion" and he was elected t.:e third member of the bench. We succeeded Williams, Greene and Hall.

Woodward was a scholarly man and from New England. Related to the Curtis family of Massachusetts on his mother's side. He was a graduate, and I think with distinction, of an eastern college, and settled in Iowa before 1840, I believe. Lowe, Hastings, Whicher, Deshler, and after that, Butler, were his confreres in Muscatine. Was apt to be precise and punctilious in his conversation and manner. Made effort beyond most men of the court to find the exact word to convey his meaning. Singularly neat in his dress, mindful of his step and demeanor, in manner without intention cold and little cordial, he was not apt to be popular with the people and yet was esteemed very highly by those who knew him intimately. He was a good and learned lawyer, and a painstaking and able judge. Was slow and methodical in the preparation of opinions, and few things pleased him more than to get at, for the state, a new question, to study it, examine the cases and elaborate it in an opinion. Isbell or myself would write an opinion in half the time that he would, not (speaking for myself) so well, it may be, but we would write while he was preparing his data. 
Take the case of McManus vs. Carmichael, 3 Iowa 1 (Riparian Rights) and Morrow vs. Weed, 4. Iowa 77 (Sale by Administrator), perhaps his most elaborate opinions, and I have no doubt that he spent weeks and even months in their preparation. This was because his mind moved slowly, and a pride seldom equalled to commend his conclusions and the reasons therefor to the profession. But for an unfortunate habit he would have been returned to the bench, for he had qualifications for the place-fine education, experience and ability to discuss and present his views, which have seldom been surpassed in the state.

He was of medium stature, a pleasant and rather an inviting face, in weight say 160 to 170 pounds. Very dignified as a rule, he seldom told a story or seemed, save in exceptional instances, to be much stirred or amused by those of others.

To show how the ablest and most painstaking of bench and bar may overlook what is nearest and look afar off-Woodward was one of the Code Commission of 1851 (Mason and Hempstead with him). He wrote the opinion on State vs. Callendine, 8 Iowa 288. In consultation he had agreed to reverse on the ground of "proven property" and he was to prepare the opinion in vacation. When we met again he read an opinion, and then after reading on the point ............, ${ }^{1}$ stated that there was another question new to the state and of very great interest fully argued by counsel in writing, and though not necessary to the disposition of the case he had .............. prepared his views and would read. Thereupon he proceeded to deliver as a second point that the indictment was bad, however it did not charge or disclose an intention to defraud some one in particular, and in support cited and quoted from case after case in common law and in other states. When he had concluded, his attention was called by one of us to the Code, 1851, Sec. 2927, declaring that such allegation was unnecessary. So that good and faithful judge had forgotten that in a book which he had assisted in preparing, the very rule which he had so elaborately discussed in ten pages, more or less, was authoritatively settled and adverse to his conclusions. How apt we are to look away off instead of at home for the law! $\mathrm{He}$ was not by any means an exception.

\footnotetext{
1These ellipses indicate words in Judge Wright's manuscript which we were unable to decipher. The Judge wrote a hand notably hard to read, besides in this instance he used a poor pencil.-Editor.
} 
He was a member of the Senate after this, the Ninth General Assembly, and had good rank, but not such as his learning, experience, and ability entitled him. This because of his habits. He was, however, always a gentleman, courtly and courteous, and his work on the bench will ever give him good rank as a jurist.

Norman W. Isbell, the other first colleague, was of different mold. His education was not so erudite, but his was a logical mind. Seldom troubled himself about more than the very point of the case, and that disposed of, he was done. Impatient of restraint, tenacious of his views, did not much like to have them controverted, and if he changed, it was more apt to be the result of his own patient thought rather than argument or discussion, whether mild or warm. He was an exceedingly fine, just, and honest man. Seldom wrote much. Chance vs. T'emple, 1 Iowa 179 , is an exception-mandamus. We used to call that "Isbell on Mandamus." Loved to listen to a good, clear, well-treated argument and was restless beyond endurance under the words of one who had evidently studied his case but little and knew less. His was an active brain, quick and of the most vigorous common sense, but the bench, while in many respects agreeable, was its because of the meager pay, $\$ 1,000$ per annum. He wanted to make, and had an ambition for money. So he resigned in 1856 and engaged in railroading. I always thought it was a mistake for he had many elements of a strong jurist and if he had remained would have made his mark. Health not very good, he quit railroading, went to California, but little relieved in health, returned, after that was on the district bench, acquitted himself well, but had to submit to the destroyer when little past middle life, leaving a royal good family and a name of which they and his friends may well be proud.

He was from Ohio-came to Marion very poor. This anecdote he told me. Engaged to be married before coming out. After a few years he thought he was able to support himself and wife. Too poor to go there and return. They had the good sense and independence to liave her come with some friends. She arrived. He was engaged in working on his house. Learning of her arrival, he arrayed himself in his best, called on her, obtained the license and they, as soon as the clergyman could be obtained, were made one. And then they started on the trip 
together. Whatever others may be inclined to say of this plan, I always admired their independence and good sense and am sure that they never lost in the estimation of the good and sensible of their many, very many friends.

Ralph P. Lowe was, 1859, with Baldwin and Stockton, the first judges elected by the people under the Constitution of 1857 . (Before that the legislature had elected.) He had been a member of the First Constitutional Convention, then living in Muscatine, also district attorney and judge of the First District, having removed to Keokuk, and governor-[then] went from the latter office to the Supreme Court bench, and during the first term became chief justice. He was also the Whig candidate for territorial delegate in Congress in 1845 , but having as his of the deserving General Dodge, and with a large political majority against him, was of course defeated. Stockton having deceased, as already stated, I succeeded him, and in June, 1860, therefore, was with him [Lowe] and Baldwin.

He was from Ohio, but his earlier days, in the law, were passed south, I believe in Alabama. A most earnest man, in all his connections he was an impressive public speaker, and though I never met him at the bar I should think him among those advocates who would be strong before a jury. He was a man of the most undoubted and undaunted courage-and with all his Presbyterianism (he was a ruling elder for years) he would resent an insult to self or friend by a blow, or more if necessary to overcome or subdue.

When General Belknap, his one time partner and old time friend, was in trouble in 1876 (Judge Lowe then being and having an office in Washington) a gentleman and client one evening while the Judge was engaged in another part of the office, spoke most disparagingly of General Belknap. The Judge could not but hear, and through with his engagement he turned and said, "You said, sir, some wicked things of my [friend] the General, who is just now in trouble and I request you to take it back." The answer was, "And suppose I don't, what will you do?" Taking him by the shoulder, the Judge said, "I will break your head and pitch you down the stairs, for no man can abuse my friend in my presence and in his absence with impunity." 
The man was his client, and finding that he must retract or suffer the consequences, he made his peace.

Another instance: At a time of consultation at the hotel in Keokuk, Baldwin and myself waited for him one evening. From the window I had seen him approaching, so after some delay I stepped to the office, and just as I cntered I heard him say to a gentleman from New York with whom it seems he had been in conversation, "You have insulted me because you spoke adversely and untruthfully of my friend, Mr. _-_ The gentleman tried to explain that he intended no offense-that he was the Judge's friend-but all of no avail, for the Judge, with arm uplifted, said in the most emphatic manner, "Take it back or I will smash your face." He retracted.

But for those who knew his devotion to his friends, the impetuosity of his nature and his well-known courage, such instances were rare. If a stranger ever trespassed, he seldom if ever made a like mistake.

He was honest himself and confiding; he was the most credulous man for his ability and long and varied experience I. ever knew. The man of fair plausibility could impose upon him, get his money or aid, and his sympathies would run out overwhelmingly whether in means, if he had them, or influence. For this and other reasons he was always comparatively poor, and yet he lived like a prince as far as he could-hospitable to a fault, a friend was never turned away, nor those poor, in his opinion, whether so in fact, denied, if asking, without help to the extent, if not beyond, his ever short purse. A strong, well-put statement by counsel caught his ear, captured him and he was ready to decide. Once $I$ know, in support of a motion, an attorney, very able, forcible and a most ready and agreeable talker, made a very conclusive and pathetic statement of the facts. I looked at the Judge and the tears had started. Turning to me he said, "We must grant that motion." I very dryly and I suppose somewhat coldly remarked that perhaps we had better first hear the other side. Apparently much hurt and not a little surprised, he said, "My Lord, you don't think he tells a lie, do you?" The motion, I may add, was finally granted, so that in this as in many instances his heart was right.

He was Governor. A convict feigned illness, and the Judge 
seeing him was made to believe, as were physicians also, that if longer confined he would soon die-that mercy demanded his release, and released he was. It was soon disclosed that a fraud had been practiced, and the Governor, meeting the ex-convict on the street, took him by the collar and said: "You lied, sir, you lied! You are a fraud! And now you leave the state within twenty-four hours or I will have you returned to the penitentiary." And he left.

Such a man could not well be a very great or profound judge. He was ever honest, always sought for the right and to do justice between suitors. But unconsciously he was in danger of being misled by a hard case, plausibility of argument, or possibly, without realizing it, prejudiced on the question or controversy. He never took much time in the disposition of a casedecided the question and seldom ventured upon much elaboration. He was wont to say that common sense was worth more to a judge than an appeal to cases or text books. Once in his offliand and jolly way he said: "This is the strongest court in the land. Baldwin has the weight, Wright the law, and I the common sense!" I fear that aside from the weighty member (he weighed 430 pounds) his claims were hardly justified. Was a man of the best impulses, frank, social qualities, and a favorite in every circle. Few men were more popular with the masses, and hence he, when a candidate for any office was apt to lead lis ticket.

He did not love work, few do, and yet he was fairly industrious. Not handling a very ready pen, he wrote with difficulty, and tired of a case, so that he often cut it off without other or further elucidation, of which he was capable, [and] which would have greatly strengthened his conclusions. He was agreeable in the consultation room-not of ten combative or so decided as not to be moved or changed, and yet he had according to his ideas, such a keen sense of the right that he was ready to brush aside all technicalities, and would sometimes do it against all opposition. 
Copyright of Annals of Iowa is the property of State of Iowa, by \& through the State Historical Society of Iowa and its content may not be copied or emailed to multiple sites or posted to a listserv without the copyright holder's express written permission. However, users may print, download, or email articles for individual use. 